\title{
SURVIVABILITY OF LACTOBACILLI CELLS UPON COATING WITH METHACRYLIC ACID COPOLYMERS
}

\author{
C.S.C. ThAM ${ }^{\mathrm{a}}$, K.K. PeH ${ }^{\mathrm{b}}$ and M.T. LIONG ${ }^{\mathrm{a} *}$

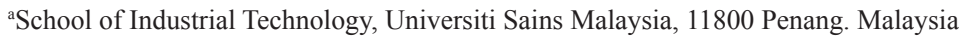

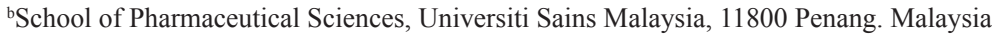

(Received: 12 September 2012; accepted: 5 November 2012)

\begin{abstract}
This study aimed to evaluate the coating effect of methacrylic acid copolymers (MAc) on alginate beads, with respect to protection, survivability, and in vitro release of lactobacilli cells under simulated gut conditions, and to evaluate the effect of oven drying and fluidized bed-spraying as a mean to dry and coat alginate beads with MAc. MAc-coated beads exhibited protective effects for lactobacilli cells against low acidic environment providing higher survivability $(71.82-96.11 \%)$ compared to uncoated beads (28.67-61.68\%), and also higher cell release under sequential gut conditions $(\mathrm{P}<0.05)$. Lactobacillus casei $\mathrm{BT} 1268$ showed a high cell release and was thus selected for further analysis using spray coating-drying via fluidized bed. Scanning electron microscopy revealed that fluidized bed-spray drying produced beads with irregular shapes but consistent coating and with lactobacilli cells clearly embedded within the inner matrix. Oven dried and fluidized bed-spray dried MAc-coated beads of $L$. casei BT 1268 also showed similar cell release, indicating the possible use of fluidized bed-spray as a more economical and less time consuming method for the protection and maintenance of cell viability.
\end{abstract}

Keywords: methacrylic acid copolymers, enteric coating, alginate, fluidized bed, Lactobacilli

"Many strains of Lactobacillus have been associated with health and nutritional benefts for the maintenance and proliferation of healthy intestinal microflora (Liong et al., 2007), attributed to their abilities to produce acids and at the same time, surviving in acidic environment (Liong \& SHAH, 2005)." The acidic conditions of the stomach and the presence of bile often render putative probiotics to be inactivated or dead upon arrival at the ileocolonic region. Hence, colon targeted delivery is important in protecting and delivering putative probiotics to the large intestines. Encapsulation techniques offer a promising approach in protecting the viability and functionality of lactobacilli cells against the bactericidal effects of the gastrointestinal environment.

Alginate is widely used natural resources matrix in improving the survivability of lactobacilli cells in food products, for up to $80-95 \%$ (MANDAL et al., 2006). However, alginate alone is insufficient to protect probiotics against the varying $\mathrm{pH}$ and enzymes along the gastrointestinal tract, attributed to the low stability of alginate gel in low $\mathrm{pH}$ environments and susceptibility to disintegration in the presence of chelating agents (CHÁvARRI et al., 2010). Some $\mathrm{pH}$-sensitive polymers such as methacrylic acid copolymers (MAc) have been used for enteric coating purposes as they are able to slowly release active moieties via an ion-exchange dependent process, due to the partial neutralization of the methacrylic acid units consisting of carboxylic acid groups (TATAVARTI et al., 2008).

The important step in the effective encapsulation of bioactives is the drying of calcium alginate beads for long-term storage. Conventional drying and coating are time consuming and costly, attributed to a two-step operation. Hence, there is an increased interest in fluidized

\footnotetext{
* To whom correspondence should be addressed.

Phone: 04-653 2114; fax: 04-657 3678; e-mail: mintze.liong@usm.my
} 
bed as an emerging economical technology for drying and coating because it is a one-step, enclosed operation. Fluidized bed dryer is used both to dry and coat various products due to the possible incorporation of a spray within the fluidized bed dryer for the additional coating onto the products.

This study aimed to evaluate the survivability of lactobacilli cells under simulated gastrointestinal conditions, upon encapsulation with alginate and coated with MAc as a model for anionic carboxylated polymers. This study also aimed to further evaluate the protection and in vitro release of cells using spray coating-drying via fluidized bed as compared to oven drying.

\section{Materials and methods}

\subsection{Bacterial cultures}

Lactobacillus acidophilus FTDC 8933, L. delbrueckii subsp. bulgaricus FTDC 8913, L. acidophilus FTDC 2131, L. acidophilus FTCC 0291, L. acidophilus BT 1088, and L. casei BT 1268 were obtained from the Culture Collection Centre of the School of Industrial Technology, Universiti Sains Malaysia (Penang, Malaysia). The strains were propagated as previously described by THAM and co-workers (2011).

\subsection{Encapsulation of lactobacilli in alginate beads}

Individual cell suspension of lactobacilli at an initial concentration of $9.0 \log \mathrm{CFU} \mathrm{ml}{ }^{-1}$ was added at a ratio of $1: 5(\mathrm{v} / \mathrm{v})$ to alginate solution $(1.5 \%, \mathrm{w} / \mathrm{v})$ and gently dispersed using a pipette into a beaker containing $0.1 \mathrm{M}$ of calcium chloride (Sigma-Aldrich). The distance between the orifice of the pipette tip and the surface of calcium chloride solution was $6 \mathrm{~cm}$. Beads were left to solidify $\left(30 \mathrm{~min}, 27^{\circ} \mathrm{C}\right.$ ), separated by filtration, washed with sterile distilled water to remove excess calcium ions, and collected.

\subsection{Conventional dip-coating and oven-drying}

A coating solution was formed via dissolving MAc (Fisino, Hangzhou, China) in sterilized distilled water $(15 \%, \mathrm{w} / \mathrm{v})$. The alginate beads $(15 \mathrm{~g})$ were then immersed in $100 \mathrm{ml}$ of coating solution and agitated at 100 r.p.m. for $10 \mathrm{~min}$. The coated alginate beads were then washed and oven dried at $40{ }^{\circ} \mathrm{C}$ till constant weight. The mean diameter of the dried beads was approximately $1.03 \pm 0.04 \mathrm{~mm}$.

\subsection{Enumeration of entrapped lactobacilli cells under in vitro human simulated gastric conditions, simulated intestinal conditions, and simulated sequential conditions}

Simulated gastric and intestinal conditions were prepared as previously described (PACHECO et al., 2010). Briefly, $1 \mathrm{~g}$ of dried beads was treated for $90 \mathrm{~min}$ in $10 \mathrm{ml}$ solution simulating gastric conditions (SGF) and for $180 \mathrm{~min}$ in $10 \mathrm{ml}$ solution simulating intestinal conditions (SIF) in vitro, or sequentially as follows: $2 \mathrm{~h}$ in $10 \mathrm{ml}$ of SGF solution, $3 \mathrm{~h}$ in $10 \mathrm{ml}$ of SIF solution, and $2 \mathrm{~h}$ in $10 \mathrm{ml}$ of phosphate buffer $(\mathrm{pH} \mathrm{7.4)}$ that mimics the ileocecal $\mathrm{pH}$. The released cells from the beads into the medium after sequential conditions were enumerated via the pour plate method. 


\subsection{Preparation of Lactobacillus casei BT 1268 cells encapsulated in fluidized bed-spray dried alginate-MAc}

Cell suspension of $L$. casei BT 1268 was added at a ratio of 1:5 (v/v) to alginate solution $(1.5 \%, \mathrm{w} / \mathrm{v})$. One millilitre of the sodium alginate-lactobacilli suspension was gently dispersed into a beaker containing $0.1 \mathrm{M}$ of calcium chloride. Beads were left to solidify in calcium alginate for $30 \mathrm{~min}$ at $27^{\circ} \mathrm{C}$. Beads were separated by filtration, washed with sterile distilled water, and collected. Beads were then dried in a fluidized bed until a constant weight has been obtained. Dried beads (30 g) were coated with MAc aqueous solution ( $15 \%, \mathrm{v} / \mathrm{v}$ ) for $16 \mathrm{~min}$ and subsequent drying at $40{ }^{\circ} \mathrm{C}$ for $10 \mathrm{~min}$. The mean diameter of the beads formed was approximately $1.34 \pm 0.04 \mathrm{~mm}$.

\subsection{Scanning electron microscope}

The thickness of the coating and the morphological properties of the cross sections of the oven dried and fluidized bed-spray dried beads as well as the internal structure characteristics of beads were evaluated using scanning electron microscope (SEM) as previously described by GAO and co-workers (2006).

\subsection{Statistical analysis}

Data analysis was carried out with SPSS Inc. software (version 14.0; SPSS Inc., Chicago, IL). T-test and One-way ANOVA were used to study significant difference between means, with significance level at $\alpha=0.05$. Tukey's test was used to perform multiple comparisons between means. All data are presented as mean \pm standard error of means. All analyses were performed in triplicates, $\mathrm{n}=3$.

\section{Results and discussion}

\subsection{Survival of lactobacilli cells in uncoated alginate beads and MAc-coated alginate beads under in vitro simulated human gastric conditions}

Lactobacilli must remain viable during transit in the gastrointestinal tract to exert their beneficial effects to the hosts. The $\mathrm{pH}$ of simulated gastric fluid was maintained at $\mathrm{pH} 2$ for $90 \mathrm{~min}$ to mimic that of the stomach. Gastric emptying time was reported to be $1.2 \pm 0.3$ hours in normal subjects (READ et al., 1986). At pH 2, viability was consistently reduced by 1.0-2.0 $\log$ CFU ml ${ }^{-1}$ every 30 min (data not shown), although encapsulated cells showed greater tolerance $(\mathrm{P}<0.05)$ towards simulated gastric condition for $90 \mathrm{~min}$. Microencapsulation with alginate was insufficient to protect the microorganisms under extreme acidic conditions, such as that of $\mathrm{pH} \mathrm{2,} \mathrm{attributed} \mathrm{to} \mathrm{the} \mathrm{susceptibility} \mathrm{of} \mathrm{alginate} \mathrm{gels} \mathrm{at} \mathrm{low} \mathrm{pH}$. Low $\mathrm{pH}$ causes a reduction in the molecular weight of the alginate leading to faster degradation and release of active moieties when re-equilibrated in neutral pH media (KRASAEKROOPT et al., 2004). Calcium alginates are also more prone to disintegration in the presence of $\mathrm{Ca}^{2+}$ chelating agents and excess monovalent ions (BRINQUES \& AyUB, 2011). The viability of lactobacilli cells in MAc-coated alginate beads showed lower log reduction compared to uncoated alginate beads for up to $90 \mathrm{~min}$ (data not shown). This may be attributed to the ingress of acid into the film coat instead of directly reacting with alginate. 


\subsection{Survival of lactobacilli cells in uncoated alginate beads and MAc-coated alginate beads under in vitro simulated human intestinal conditions}

The $\mathrm{pH}$ of simulated intestinal fluid was adjusted to 6.8 , akin to small intestinal $\mathrm{pH}$ conditions. The viability of lactobacilli in uncoated alginate beads and MAc-coated alginate beads decreased proportionately $(\mathrm{P}<0.05)$ with time under simulated intestinal conditions. MAc is resistant to $\mathrm{pH} 6.8$, protecting the lactobacilli cells in the alginate beads, hence contributing to the lower reduction of viability as compared to uncoated alginate beads.

\subsection{Survival and release of lactobacilli cells in uncoated alginate beads and MAc-coated alginate beads under in vitro simulated human sequential conditions}

The colon is considered an ideal site for attachment of lactobacilli cells and deemed suitable for adsorption of active compounds because of the very low oxidation-reduction potentials, lack of oxygen supply, and the slow intestinal motility. Thus, the effective release of lactobacilli cells is crucial for the attachment and colonization of the microorganisms at colonic regions. Percentage of cell release from MAc-coated alginate beads was greater compared to uncoated alginate beads (Fig. 1). Partial neutralisation of the carboxylic acid units of the MAc is $\mathrm{pH}$ dependent and reaches maximum at $\mathrm{pH}>7.0$, where the polymers begin to solubilise due to the increased water uptake. Thus, the higher percentage of cell release for cells encapsulated in alginate beads coated with MAc (compared to uncoated beads) was attributed to the enhanced protection of viable cells during transit in the gastrointestinal tract and the complete release of viable cells into the medium at $\mathrm{pH} 7.4$.

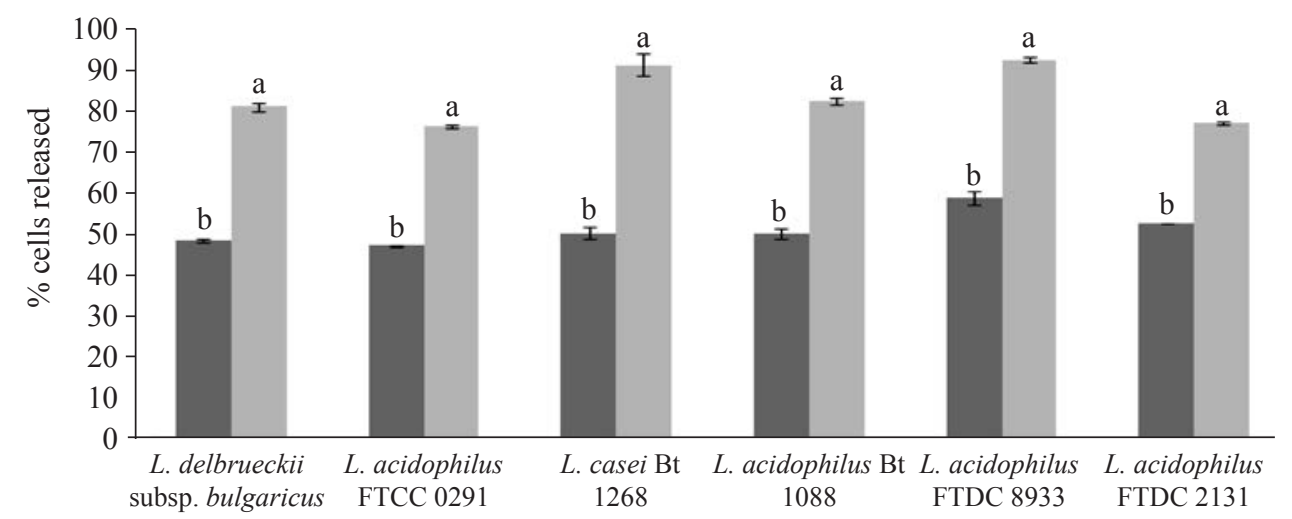

FTDC 8913

Strains

Fig. 1. Percentage of lactobacilli cells in uncoated alginate beads and methacrylic acid copolymers-coated alginate beads released into simulated sequential fluid*. Results are expressed as the mean \pm standard error; each data point is the average of three separate runs, $n=3$. ${ }^{\text {ab }}$ Means strains with different lowercase superscript letters are significantly different $(\mathrm{P}<0.05)$. Simulated sequential fluid: $2 \mathrm{~h}$ in simulated gastric condition $(\mathrm{pH} 2.0)$, followed by $3 \mathrm{~h}$ in simulated intestinal condition ( $\mathrm{pH}$ 6.8), and $2 \mathrm{~h}$ in simulated colon condition (pH 7.4).

$\square$ : uncoated alginate beads; $\square$ : 2-methylprop-2-enoic acid coated alginate beads

\subsection{Fluidized-bed coating and drying}

Lactobacillus casei BT 1268 was chosen for further drying and coating using fluidized bed, because this strain was evaluated in our previous study (ThAm et al., 2011) to have statistically better probiotic properties as well as high cell release in the current study. Fluidized bed- 
spray dried beads showed similar cell release of $91.89 \pm 0.45 \%$ compared to oven dried beads $(91.79 \pm 4.91 \%)$. Fluidized bed dryer is commonly used, because once the capsules have been dried, extra protection can be achieved by spraying of enteric coating onto surface. The coating and drying process used in this study is bottom spray, which is well acknowledged for the quick drying time, uniformity, efficiency, and homogeneity in coating. Apart from that, the relatively low cost of operation as well as the suitability for heat sensitive materials due to the low drying temperature, high drying rate, and high energy efficiency, promote the productivity and stability of the active moieties within the capsules (ТАТЕмото et al., 2007). Meanwhile, oven drying is time consuming, as the beads tend to clump together unless manually separated during drying, whereas fluidized bed produced dried granular beads with shorter drying time (Cook et al., 2011). In addition, oven dried beads may also develop a small level of surface cracking during separation due to the clumping on flat surfaces or clumping on other beads.

\subsection{Scanning electron microscope}

Bead size and morphology are influenced by various factors, such as hardening time, drying of beads, coating rate as well as types of drying conditions. Hardening time of 30 minutes in $0.1 \mathrm{M}$ calcium chloride resulted in the decrease of bead size, smoother and a more spherical shaped bead (SMrDEL et al., 2008). Oven dried beads have irregularly shaped spheres with roughs on the surface due to quick loss of water (LóPEZ-CACHO et al., 2012). As water evaporates from the surface of the beads, water from the interior of the beads is continuously drawn to the surface and expelled. On the other hand, fluidized bed dried beads normally have a shrunken shape, with flattened or irregularly folded shaped spheres. This is attributed to the rapid drying of both the bead surface and the liquid in the inner part of the bead causing the bead to collapse (SMrdel et al., 2008). Although fluidized bed-dried beads shrunk and showed irregular shapes, the entire perimeter of the beads were consistently covered with coating material. More importantly, the percentage of cell release from fluidized bed-dried beads was the same as oven dried beads, which were more spherically shaped. The cross sections of the coated beads showed a dense and compact interior (Fig. 2A \& 2B) (SMRDEL et al., 2008). High porosity of beads was mechanically weaker and uptake of water into the matrix was greater compared to beads with a denser and compact interior (GAL \& NUSSINOVITCH, 2007). Thus, we postulate that beads produced via oven drying and fluidized-bed drying provided a stable interior that prevented the fast release of active moieties under gut conditions. MAc are anionic copolymers made up of methacrylic acid and methyl esters. The ability of MAc to coat alginate beads is attributed to the binding of the carboxylic acid group in methacrylic acid to $\mathrm{Ca}^{2+}$ ions in the alginate matrix (TIERA et al., 1998). The embedded lactobacilli cells were also immobilized efficiently in the interlinking alginate network (Fig. 2C). Immobilization provided protection and also improved the survivability of cells by preventing the leakage of cells into the detrimental environments that may cause cell death.

\section{Conclusions}

Alginate beads coated with MAc have shown to exhibit appropriate cell release prior to arrival at the ileo-colonic regions for attachment. This matrix may serve as a potential colon targeted polymer for the delivery of probiotic microorganisms. This may eventually serve as an economical alternative for the encapsulation of probiotics in tandem with the increasing 
demands of probiotics, attributed to their potential applications in various health, therapeutic and prophylactic effects. Hence, fluidized bed may serve as a promising drying method for the protection and maintenance of cell viability.

A

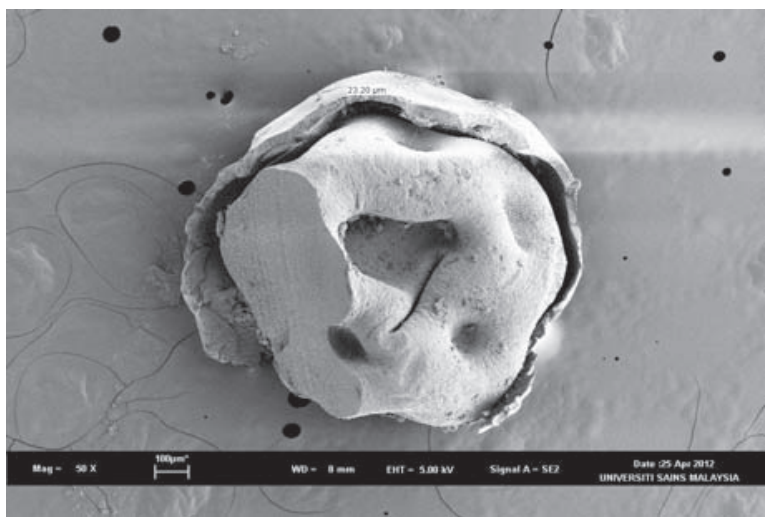

$\mathrm{B}$

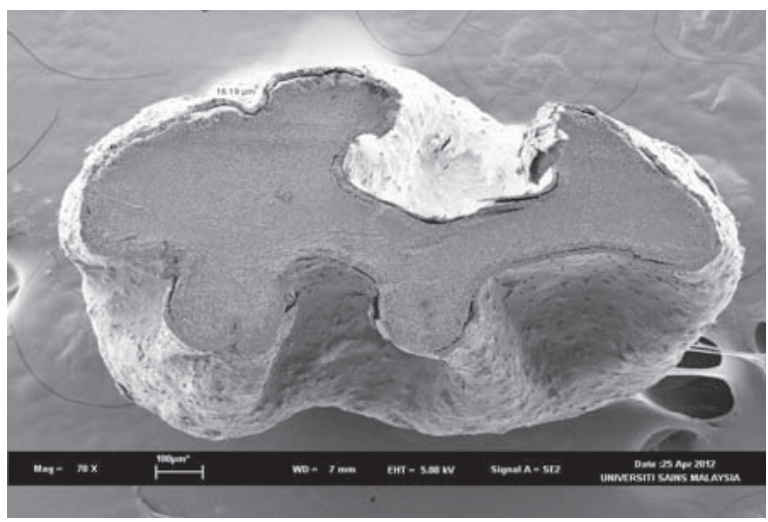

$\mathrm{C}$

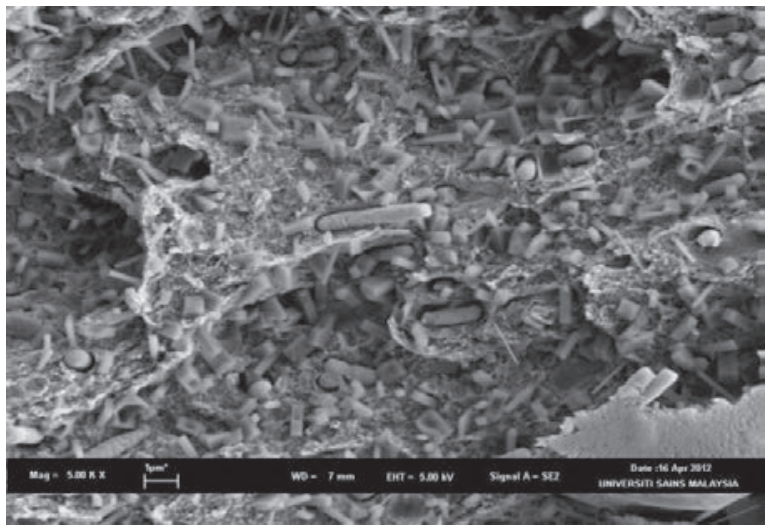

Fig. 2. Scanning electron micrographs of cross-sectioned alginate bead (A): upon coating with methacrylic acid copolymer via oven drying; (B): upon fluidized bed-spray drying for $16 \mathrm{~min}$, and (C): Lactobacillus casei BT 1268 cells embedded in the matrix of methacrylic acid-coated alginate beads 


\section{References}

Brinques, G.B. \& Ayub, M.A.Z. (2011): Effect of microencapsulation on survival of Lactobacillus plantarum in simulated gastrointestinal conditions, refrigeration and yoghurt. J. Fd Engng, 103, 123-128.

Chávarri, M., Marañón, I., Ares, R., Ibáñez, F.C., Marzo, F. \& Villarán, M.C. (2010): Microencapsulation of a probiotic and prebiotic in alginate-chitosan capsules improves survival in simulated gastro-intestinal conditions. Int. J. Fd Microbiol., 142, 185-189.

Cook, M.T., Tzortzis, G., Charalampopoulos, D. \& Khutoryansky, V.V. (2011): Production and evaluation of dry alginate-chitosan microcapsules as an enteric delivery vehicle for probiotic bacteria Biomacromolecules, 12, 2834-2840.

GaL, A. \& Nussinovitch, A. (2007): Hydrocolloid carriers with filler inclusion for diltiazem hydrochloride release. J. Pharm. Sci., 96, 168-178.

Gao, C., Huang, J., Jiao, Y., Shan, L., Liu, Y., Li, Y. \& Mei, X. (2006): In vitro release and in vivo absorption in beagle dogs of meloxicam from Eudragit ${ }^{\circledR}$ FS 30 D-coated pellets. Int. J. Pharm., 322, 104-112.

Krasaekroopt, W., Bhandari, B. \& Deeth, H. (2004): The influence of coating materials on some properties of alginate beads and survivability of microencapsulated probiotic bacteria. Int. Dairy J., 14, 737-743.

López-Cacho, J.M., González-R, P.L., Talero, B., Rabasco, A.M. \& González-RodríGuez, M.L. (2012): Robust optimization of alginate-carbopol 940 bead formulations. Scient. World J. doi:10.1100/2012/605610

Mandal, S., PuniYa, A.K. \& Singh, K. (2006): Effect of alginate concentrations on survival of microencapsulated Lactobacillus casei NCDC -298. Int. Dairy J., 16, 1190-1195.

Pacheco, K.C., Del Toro, G.V., Martinez, F.R. \& Durán-PÁramo, E. (2010): Viability of Lactobacillus delbrueckii under human gastrointestinal conditions simulated in vitro. Am. J. Agr. Biol. Sci., 5, 37-42.

Read, N.W., Al-Janabi, M.N., Holgate, A.M., Barber, D.C. \& Edwards, C.A. (1986): Simultaneous measurement of gastric emptying, small bowel residence and colonic filling of a solid meal by the use of the gamma camera. Gut, 27, 300-308.

Smrdel, P., Bogataj, M. \& Mrhar, A. (2008): The influence of selected parameters on the size and shape of alginate beads prepared by ionotropic gelation. Sci. Pharm., 76, 77-89.

Liong, M.T., \& Shah, N.P. (2005): Production of organic acids from fermentations of mannitol, FOS and inulin by a cholesterol removing Lactobacillus acidophilus strain. J. Appl. Microbiol., 99, 783-793.

Liong, M.T., Dunshea, F.R. \& Shah, N.P. (2007): Effects of a synbiotic containing Lactobacillus acidophilus ATCC 4962 on plasma lipid profiles and morphology of erythrocytes in hypercholesterolaemic pigs on high- and low-fat diets. Brit.J. Nutr., 98, 736-744.

Tatavarti, A.S., Muller, F.X. \& Hoag, S.W. (2008): Evaluation of the deformation behavior of binary systems of methacrylic acid copolymers and hydroxypropyl methylcellulose using a compaction simulator. Int. J. Pharm., 348, 46-53.

Tatemoto, Y., Mawatari, S.Y., Noda, K. \& Komatsu, N. (2007): Drying characteristics of porous material immersed in a bed of glass beads. Chem. Engng Sci., 62, 471-480.

Tham, C.S.C., Peh, K.K., Bhat, R. \& Liong, M.T. (2011): Probiotic properties of bifidobacteria and lactobacilli isolated from local dairy products. Ann. Microbiol., 62, 1079-1087.

Tiera, M.J., De Oliviera, V.A., Burrows, H.D., Miguel, M.G. \& Neumann, M.G. (1998): Fluorescence study of the interaction between metal ions and methyl methacrylate-methacrylic acid copolymers in aqueous solutions: thallium (I), calcium (II), and terbium (III). Colloid Polym. Sci., 276(3), 206-212. 